\title{
A Quasi-Experimental Pilot Study Examining the Effects of Spiritual Nursing Care Education Based in Biblical Truth on Pediatric Nurses' Competence in Providing Spiritual Nursing Care
}

Bethany F. Linegang

Cedarville University, blinegang@cedarville.edu

Follow this and additional works at: http://digitalcommons.cedarville.edu/nursing theses

Part of the Nursing Commons

\section{Recommended Citation}

Linegang, Bethany F., "A Quasi-Experimental Pilot Study Examining the Effects of Spiritual Nursing Care Education Based in Biblical Truth on Pediatric Nurses' Competence in Providing Spiritual Nursing Care" (2014). Master of Science in Nursing Theses. 9.

http://digitalcommons.cedarville.edu/nursing_theses/9 

A Quasi-Experimental Pilot Study Examining the Effects of Spiritual Nursing Care Education Based in Biblical Truth on Pediatric Nurses' Competence in Providing Spiritual Nursing Care

A thesis submitted in partial fulfillment of the requirements for the degree of Master of Science in Nursing

Bethany Faith Linegang

A.D.N. Miami University, 1999

B.S.N. Miami University 2000

2014

Cedarville University 
Examining the Effects of Spiritual Nursing Care Education on Pediatric Nurses' Competence in providing Spiritual Nursing Care

Background: Spiritual care is an expectation of many governing bodies of nursing and health care. Studies have continued to show health benefits from spiritual care. However, many nurses still feel unprepared to provide spiritual nursing care to their patients.

Purpose: The purpose of this study was to examine the effects of a spiritual care inservice on pediatric nurses' perceived competence in providing spiritual care as measured by the Spiritual Care Competency Scale (SCCS). The information provided in the inservice was guided by the Faith-Hope-Love Model of Spiritual Care for Nurses which is based on a Christian Worldview.

Results: Thirty-two pediatric nurses from a large Children's Hospital in the Midwest participated in this quasi-experimental pilot study. Spiritual care competence was measured before and after the 45 minute intervention using the SCCS. On four of the six spiritual care domains measured by the SCCS, there was a statistically significance increase in the nurses' perceived competence after the in-service compared to before the in-service.

Discussion: Future research is recommended on a larger sample, longitudinal research to determine behavior change, and effects of spiritual care delivered using this model on patients. The results of this study encourage usage of the Faith-Hope-Love Model of Spiritual Care for Nurses to increase nurse's competence in providing spiritual nursing care. 


\section{Table of Contents}

$\underline{\text { Page }}$

Abstract

\section{Chapters:}

1. Introduction $1-5$

$\begin{array}{ll}\text { Barriers } & 2-3\end{array}$

$\begin{array}{ll}\text { Education } & 3-4\end{array}$

Gaps in literature $\quad 4-5$

$\begin{array}{ll}\text { Purpose } & 5\end{array}$

Hypothesis $\quad 5$

2. Conceptual Framework 6-10

3. Methods 11-16

$\begin{array}{ll}\text { Participants } & 11\end{array}$

Design $11-14$

Measurement tool`—14-16

$\begin{array}{ll}\text { Data collection } & 16\end{array}$

$\begin{array}{ll}\text { Ethical Considerations } & 16\end{array}$

4. Results 17-23

$\begin{array}{lr}\text { Demographic characteristics } & 17-18\end{array}$

$\begin{array}{lr}\text { Spiritual care competence } & 19-23\end{array}$

5. Discussion 24-31

Links to Model $\quad 26$ 
Limitations and strengths

Implications for practice

28-29

Recommendations for future research

29-30

Summary

$30-31$

References

$32-36$

Appendix

$37-43$

A. Spiritual Care Competence Survey

$37-43$ 


\section{Chapter One}

\section{Introduction}

Spiritual care has become a highly discussed issue in contemporary health care. However, the spiritual dimension of nursing care has been noted as important to healing since the days of Florence Nightingale (Macrae, 1995). In 2001, The Joint Commission (TJC) added spiritual assessment to their requirements for healthcare providers. The Code of Ethics for Nurses, written by the American Nurses Association (ANA) requires that nurses discuss and consider patients' values and beliefs when planning and implementing nursing care (American Nurses Association, 2010). Spiritual care has been shown to be beneficial on many levels. It has the potential to influence mental and physical health, immunity, cardiovascular health, and health behaviors (Koenig, 2008).

From a Christian worldview, spiritual health is closely associated with a person's relationship with God. The presence or absence of the Spirit of God is at the core of our overall health, and helps one return to a balance that completes the picture of wholeness (Kolander, 2002). In the Old Testament the Hebrew word ruach is most often translated wind from God, breath, and spirit (Shelly \& Miller, 1999). Spiritual brokenness can be worse for overall health than physical illness (Monroe \& Schwab, 2009). Without the spirit of God guiding man to achieve peace, repair relationships and find healing, one experiences a feeling of loneliness and dysfunction (Bria, 1992). Nurses trained to provide effective spiritual care can help bring both physical and spiritual healing to their patients. Van Dover \& Pfeiffer (2001) define spiritual care as caring for the human being, the human spirit; by engaging the core of who the nurse is in caring for others. 
Despite professional standards requiring spiritual care, patients still report that they do not receive adequate spiritual care. In a study of 230 patients with advanced cancer, Balboni et al. (2007) found that $88 \%$ of patients claimed religion to be important to them, but $72 \%$ stated their spiritual needs were only met minimally or not at all by medical personnel. In the same study, spiritual support by religious or medical personnel was significantly associated to a patient's quality of life $(p=0.0003)$ (Balboni et al. 2007). Astrow et al. (2007) observed that clients who reported their spiritual needs were not adequately addressed reported significantly lower levels of satisfaction with their medical care. Palliative care patients have stated that they would rather be offered spiritual care and be free to refuse it rather than it to not be offered at all (Yardley, Walshe \& Parr 2009). In a study of parents of children who have died at a pediatric hospital, parents indicated that spiritual care is very important in the care of a dying child (Weidner, Cameron, Lee, McBride, \& Mathias 2011).

\section{Barriers}

Many researchers have examined the barriers to nurses providing spiritual care. A major barrier to nurses providing spiritual care is nurses do not see themselves as spiritual caregivers (Ross, 2006 \& McEwen, 2004). Furthermore, Carr (2010) reported that nurses perceive that the rise of professionalism has labeled some spiritual care practices as crossing professional boundaries, and workplace stressors and decreased time to provide holistic care creates moral distress. These factors along with the fear of their own mortality prevent nurses from providing spiritual care (Carr, 2010). 
The biomedical model dominates healthcare and this leads to nurses looking at the body in parts that need to be fixed or maintained (Carr, 2010). The wholistic nursing care that includes spiritual care is not possible when viewing healthcare in this manner. However, the need for spiritual care is discussed in nursing literature more than any other healthcare profession (Hummel, et. al, 2008)

Kenny and Ashley (2005) found that $38 \%$ of the nurses in their study perceived lack of knowledge of self and self-awareness as barriers to spiritual care. $67 \%$ of nurses feel they lack communication skills, and $45 \%$ have inadequate education in school to be able to provide adequate spiritual nursing care. Highfield, Taylor, \& Amenta (2000) performed a study that indicated $53 \%$ of nurses stated they were inadequately prepared to give spiritual care.

\section{Education}

Meyer (2003) determined that students with education in spiritual care are more likely to describe increased awareness of spirituality in their nursing practice. However, many studies show evidence that nurses are inadequately educated to provide spiritual care. Spirituality is not included in most formal nursing education (Ross, 2006, Delaney, 2005, Hodge \& Horvath, 2006, \& Lemmer, 2002). Keefe (2005) found that more experienced nurses are returning to graduate programs with a strong spiritual component to gain more knowledge about spirituality and end of life care.

Pesut (2008) performed a comprehensive review of nursing textbooks and determined that while most nursing textbooks include information about spirituality, spirituality was discussed only as complementary therapies, faith healing, and different 
religious practices. Pesut (2008) also discussed that the current nursing literature on spiritual care uses the nursing process, and the interventions are indistinguishable from good psychosocial care.

Wallace et al. (2008) found that spiritual education in senior undergraduate nursing students had an impact on their spiritual knowledge and perspectives yet the juniors in the same study did not. The interventions varied between junior and senior students in this study making it difficult to determine effectiveness. While this study spoke of the students recognizing hope as a need of the spirit, there was no focus on Biblical reasons for spiritual care. This study was a small quasi-experimental study of pre-test/post-test design.

Burkhart \& Schmidt (2012) showed a significant increase in students' perceived ability to assess a patient's spiritual needs, and promote spiritual connections with patients after receiving training in spiritual care. Burkhart \& Schmidt's (2012) study was a randomized control trial with two cohorts at a faith-based institution. Therefore, it is only generalizable to faith-based institutions

\section{Gaps in the Literature}

There has been little research on the effect of spiritual nursing education in clinical practice (Wallace et al., 2008). I have found no research on the effects of spiritual education provided to currently practicing nurses on their competence and knowledge levels of spiritual nursing care. I have found no research discussing the benefits of an in-service on Spiritual Care for practicing nurses, but only on long 12-20 week courses. The literature suggests nurses need current spiritual care education to help 
them in understanding spiritual nursing care, identifying spiritual needs and providing interventions to their patients (Burkhart \& Hogan, 2008).

Previous research has indicated that education on spiritual care in undergraduate nurses positively affected their knowledge and ability to provide spiritual care (Burkhart \& Schmidt, 2012 \& Wallace, et al, 2008). There is limited research on education of currently practicing, experienced nurses, but it is reasonable to conclude that education to these nurses would also positively affect their knowledge and competence with spiritual care.

\section{Purpose}

The purpose of this study is to determine if spiritual nursing care education based on Biblical truth influences the competence levels of spiritual caregiving in pediatric nurses.

\section{Hypothesis}

There will be a change in pediatric nurse's perceived competence following the education session on the Faith-Hope-Love Model of Spiritual Care for Nurses. 


\section{Chapter Two \\ Conceptual Framework}

After reading various theories of spiritual care, I found that none of the theories currently available reflect a Biblical worldview of nursing. Many of the theories currently published examine spirituality as separate from God with overtly existentialist teachings. I would like to focus on spirituality directly related to God. In order to accomplish this, the theoretical background comes from the Faith-Hope-Love Model of Spiritual Care for Nurses, an unpublished work of Sharon Christman, PhD professor at Cedarville University.

The Faith-Hope-Love model states that the spirit is different from the body, but that the body and spirit are "deeply integrated with mutual functional dependence and causal connection (Christman, 2013)." The spirit is of God and of Man. The Spirit of God has three main functions. The Spirit of God fills men (Ex 31:3, 31; Numb 24:2; Judg 3:10; Judg 6:34; Sam10:6,10 \& 11; 1Chron 12:18; 2 Chron 15:1; 1 Cor 3:16; Matt 3:11; Mark 1:8; Luke 3:16; Acts 2:4; Acts 2:38), it empowers men to do extraordinary things ( 1 Sam 10 \&11; 2 Chron 15:1; 2 Chron 20:14; Judges 14:6; Deut 4:9; 1 Chron 12:18; Prov 1:23), and it leads men (1 Kings 18:12; Matt 4:1; Rom 8:14) (Christman, 2013). The spirit of man is the essence of life (Job 15:30; Psalm 104: 29-30; Eccles 12:7 Luke 23:46; Luke 8:55) (Christman, 2013). A man's spirit can be broken (Exod 6:9, 1 Sam 1:15, Job 17:1, 2 Cor 2:13), and it can be healed (Gen 45:27, Judg 15:19, 1 Sam 30:12, 1 Cor 16:18). 
Christman (2013) further states that man's spirit has essential needs of faith, hope, and love (1 Corinthians 13:13). I have examined the Biblical evidence of these spiritual needs of man. (Table 1) 
Table 1

Examination of the Needs of the Spirit

\begin{tabular}{|c|c|c|}
\hline Faith & Hope & Love \\
\hline $\begin{array}{l}\text { Can't please God without } \\
\text { Faith (Hebrews 11:6) }\end{array}$ & $\begin{array}{l}\text { Speaks of the hope of } \\
\text { resurrection (Acts 1:11, } \\
23: 6,26: 6-7)\end{array}$ & $\begin{array}{l}\text { Without Love we are } \\
\text { nothing. Love is patient, } \\
\text { kind, doesn't envy, boast, } \\
\text { be proud, dishonor others,is } \\
\text { angry. Rejoices with truth, } \\
\text { protects, trusts hope, } \\
\text { perseveres. Never Fails (1 } \\
\text { Corinthians 13:1-13) }\end{array}$ \\
\hline $\begin{array}{l}\text { God desires us to have } \\
\text { Faith in only Him (Daniel } \\
3: 18 \text { ) }\end{array}$ & $\begin{array}{l}\text { Labor because of hope in } \\
\text { God (1 Timothy } 4: 10)\end{array}$ & $\begin{array}{l}\text { Love one another (John } \\
13: 34-35,15: 13)\end{array}$ \\
\hline $\begin{array}{l}\text { Faith in times of trouble } \\
\text { (Job 13:15) }\end{array}$ & $\begin{array}{l}\text { Hope of Glory in Christ } \\
\text { (Colossians } 1: 4-5,27)\end{array}$ & $\begin{array}{l}\text { God's love is poured into } \\
\text { our hearts (Romans 5:5) } \\
\text { God works for good for } \\
\text { those that love him(Romans } \\
\text { 13:8-10, 8:28) }\end{array}$ \\
\hline $\begin{array}{l}\text { Faith brings gift of Holy } \\
\text { Spirit, salvation, and } \\
\text { forgiveness of sins (Acts } \\
2: 38,4: 12,10: 43 \text { ) }\end{array}$ & $\begin{array}{l}\text { Hope that kingdom will be } \\
\text { on earth as it is in Heaven } \\
\text { (Matthew } 6: 10 \text { ) }\end{array}$ & $\begin{array}{l}\text { Love your neighbor as } \\
\text { yourself. (Leviticus 19:18) }\end{array}$ \\
\hline $\begin{array}{l}\text { Word of God is a message } \\
\text { of Faith (Romans 10:8-10, } \\
\text { 17) }\end{array}$ & $\begin{array}{l}\text { Jesus says whoever believes } \\
\text { in him will never die. (John } \\
11: 25-26 \text { ) }\end{array}$ & $\begin{array}{l}\text { Love each other deeply. Be } \\
\text { compassionate and Humble } \\
\text { (1 Peter } 3: 8,4: 80)\end{array}$ \\
\hline
\end{tabular}




\begin{tabular}{|c|c|c|}
\hline $\begin{array}{l}\text { Faith is a gift from God } \\
\text { (Ephesians 2:8-9) }\end{array}$ & $\begin{array}{l}\text { We are the chosen people } \\
\text { (1 Peter 2:9) Spread the } \\
\text { message of Hope (1 Peter } \\
3: 15)\end{array}$ & $\begin{array}{l}\text { Only thing that has value is } \\
\text { Faith expressing itself } \\
\text { through Love (Galatians } \\
5: 6 \text { ) Love is a fruit of the } \\
\text { spirit (Galatians } 5: 22-23 \text { ) }\end{array}$ \\
\hline $\begin{array}{l}\text { We are justified not by } \\
\text { works but by Faith } \\
\text { (Galatians } 2: 16 \text { ) }\end{array}$ & $\begin{array}{l}\text { Nothing can separate us } \\
\text { from love of God (Romans } \\
8: 39 \text { ) Hope is from the } \\
\text { Holy Spirit given to us by } \\
\text { God (Romans } 5: 2-5 \text { ) Hope } \\
\text { is patient for that which is } \\
\text { not seen (Romans } 8: 23-25 \text { ). }\end{array}$ & $\begin{array}{l}\text { Love your enemies } \\
\text { (Matthew 5:43-48) Love } \\
\text { protects us from greed. } \\
\text { (Matthew 6:24) }\end{array}$ \\
\hline $\begin{array}{l}\text { Faith encourages the Holy } \\
\text { Spirit (Ephesians 1:13) }\end{array}$ & $\begin{array}{l}\text { Justified by Grace bringing } \\
\text { hope for eternal life (Titus } \\
3: 5-7 \text { ) }\end{array}$ & $\begin{array}{l}\text { Parable of the Good } \\
\text { Samaritan, Love your } \\
\text { neighbor (Luke 10:25-37) }\end{array}$ \\
\hline $\begin{array}{l}\text { Faith is one of the greatest } \\
\text { commandments ( } 1 \\
\text { Corinthians 13:13) }\end{array}$ & $\begin{array}{l}\text { Hope that we will be like } \\
\text { Christ (1 John } 3: 2-3 \text { ) }\end{array}$ & $\begin{array}{l}\text { Love with actions and in } \\
\text { truth (1 John } 3: 17-18)\end{array}$ \\
\hline $\begin{array}{l}\text { Faithfulness is a fruit of the } \\
\text { Holy Spirit (Galatians 5:22) }\end{array}$ & $\begin{array}{l}\text { Through Spirit hope for } \\
\text { righteousness (Galatians } \\
5: 5 \text { ) }\end{array}$ & $\begin{array}{l}\text { Love drives out fear (1 John } \\
4: 18 \text { ) }\end{array}$ \\
\hline \multirow[t]{2}{*}{$\begin{array}{l}\text { Through Faith we receive } \\
\text { the promise of the spirit } \\
\text { (Galatians } 3: 14 \text { ) }\end{array}$} & $\begin{array}{l}\text { Those who hope in God } \\
\text { will not be disappointed } \\
\text { (Isaiah } 49: 23 \text { ) }\end{array}$ & $\begin{array}{l}\text { Love one another ( } 1 \text { John } \\
4: 7 \text { ) and We love because } \\
\text { he first loved us. ( } 1 \text { John } \\
4: 19-21 \text { ) }\end{array}$ \\
\hline & $\begin{array}{l}\text { God has plans for us which } \\
\text { we are not aware. Plans to } \\
\text { give us hope. (Jeremiah } \\
29: 11 \text { ) }\end{array}$ & \\
\hline
\end{tabular}

Dr. Christman's model is based on the idea that our spirits need faith in something or someone; hope in the present or future; and to experience love of others and God. 
Spiritual distress occurs when lack of faith leads to fear, lack of hope leads to hopelessness, and lack of love brings about loneliness (Christman, 2013). Our nursing actions then are aimed at reducing fear, hopelessness, and loneliness by providing faith, hope and love (Christman, 2013). By developing nursing actions that address these issues one is providing spiritual care.

The independent variable in this study is spiritual nursing care in service. Spiritual care in practice is defined by an interpersonal relationship between the nurse and patient that is to increase patient spirituality (Burkhart \& Hogan, 2008). The program of education is based on the model described in the preceding paragraphs. The in service includes an explanation of the model, practical nursing interventions, and implications. The dependent variable of competence is defined from a revised definition from the National Council of State Boards of Nursing (2005) as the application of knowledge to current care practices, and use of decision-making expected for their role.

Dr. Christman's model (2013) is based on the idea that when we are able to gain knowledge about what the spirit is, we are able to provide care to the spirit. Knowledge of the spirit leads to competence in caring for the patient's spirit. When one has knowledge of the spirit and the needs of the spirit, he or she can develop plans to address spiritual distress.

I expect to show that providing Biblically-Based spiritual nursing care education will increase the pediatric nurses' competence in providing spiritual nursing care. The nurses demonstrating competence with providing spiritual nursing care will lead to an increase in the patient's spiritual needs being addressed. 


\section{Chapter Three}

\section{Methods}

\section{Participants}

This is a pilot study of Pediatric Nurses at a pediatric inpatient facility that serves over 20 counties in the Midwest. There were 32 Pediatric Nurses that agreed to participate in the study. A power analysis (effect size $=0.3$, alpha $=0.05)$ indicated a power of 0.12 . The sample is a convenience sample. Nurses at the facility were asked to voluntarily participate in the study, but all were welcome to be involved in the education. There were no exclusion criteria. Informed consent was implied with the completion of the survey which was thoroughly described in Question 1 of the survey. Continuing Education Credits were provided by the facility's Department of Corporate Education for completion of the course. Participation was not a requirement to receive credit.

\section{Design}

The hypothesis of the study is that spiritual nursing education with a Biblical perspective will have a positive effect on the pediatric nurses' competence in providing spiritual nursing care to their patients. The study is quasi-experimental with a pre-test/ post-test design. The in service was developed by a university faculty member, and was advertised by the Corporate Education Department as part of their Diversity Series. The advertising was sent via email to all nursing staff at the facility and was clearly identified as part of a study.

The intervention included a 45 minute in service by a university faculty member. The in service was offered at two separate times to accommodate the nurses' schedules. 
The in service consisted of Dr. Sharon Christman's model of spiritual nursing care (figure 1). The various components of the model were described in detail. The presenter described the spirit as described in the Bible. The spiritual needs of man were described and discussed. The presenter described and defined how the components of the model interact to meet the needs of man. The model and interactions are shown pictorially in Figure 2 (S. Christman, personal communication, October 28, 2013). The nurses were then educated on how to integrate evidenced based spiritual care interventions into the nurse's current practice. 
Figure 2. Model of Interactions of Spirit

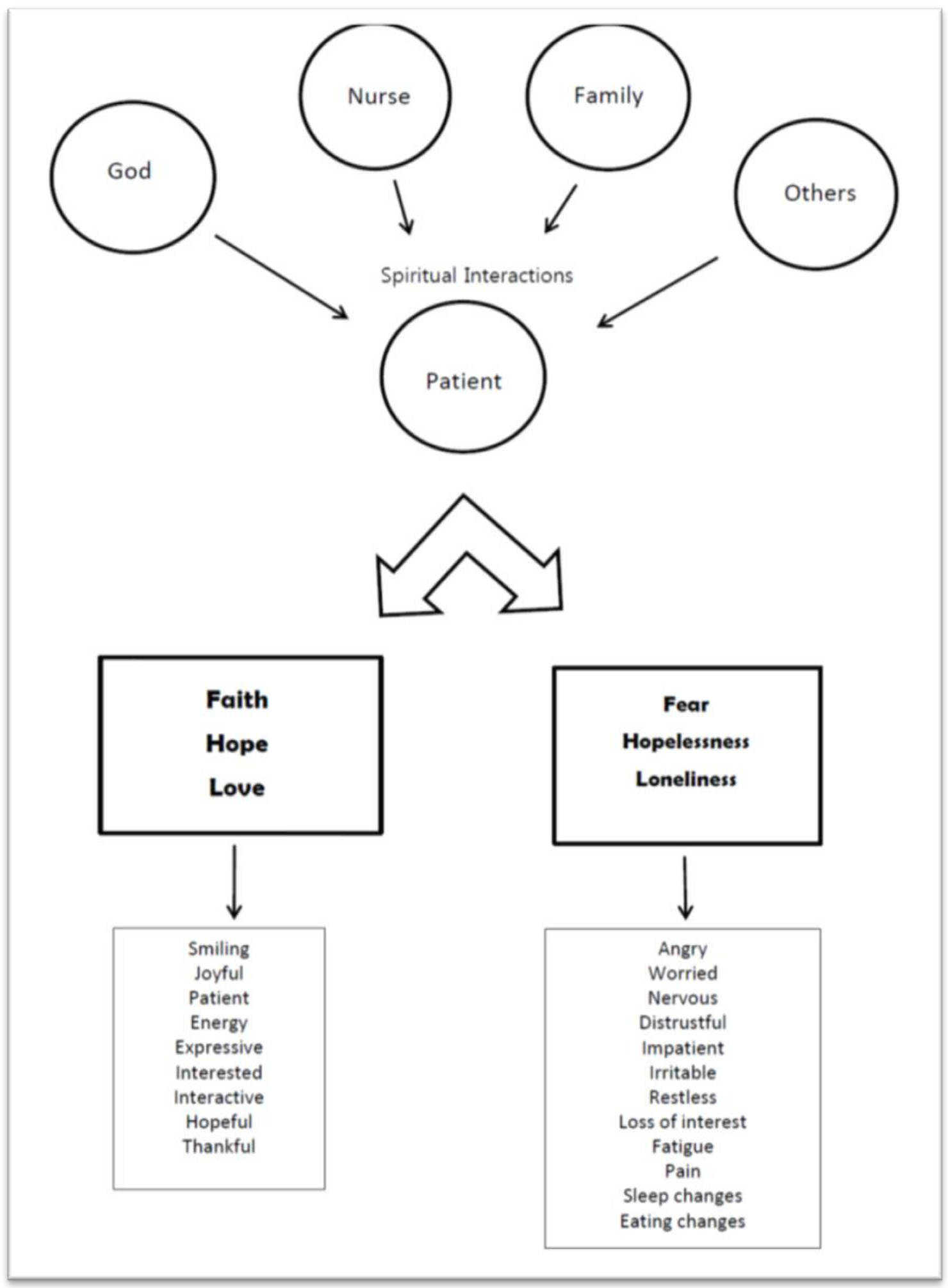


The nurses were asked to complete the SCCS via Turning Point software prior to the education session. Turning Point is a software program that allows the participants to remotely answer the pre-test questions that are projected on the screen. This program collects the data anonymously. Immediately following the pre-test, the spiritual care inservice was offered Following the in-service, nurses were handed a paper copy of the SCCS and asked to fill it out and return as soon as possible. There were 32 nurses who completed the pre-test, and 20 completed and returned the post-test.

\section{Measurement Tool}

The dependent variable in this study is competence. The dependent variable of competence was operationally defined as the score on the individual domains of The Spiritual Care Competence Scale (SCCS) developed by Van Leeuwen (2004). This scale consists of six core domains: assessment and implementation of spiritual care, professionalization and improving quality of spiritual care, personal support and patient counseling, referral to professionals, attitude towards patient's spirituality, and communication (Van Leeuwen, Tieslinga, Middel, Post, \& Jochemsen, 2009). An increase in competence is defined as the increase in the score on the SCCS. The competencies were determined based on literature reviews by above researchers.

A study was done with nursing students to determine the validity and reliability of the SCCS (Van Leeuwen et al., 2009). Factor Analysis was used to evaluate the construct validity, and internal reliability was tested using Cronbach's Alpha and Mean Inter-item Correlation (Van Leeuwen et al., 2009). The researchers used a Cronbach's Alpha score greater or equal to 0.70 and a MIIC greater or equal to 0.25 (Van Leeuwen et 
al., 2009). Internal consistency was present in each of the six core domains of the competencies (Van Leeuwen et al., 2009). Van Leeuwen et al (2009) determined that the SCCS was a valid and reliable scale for measuring the spiritual care competence of nurses.

A separate study by Van Leeuwen, Tiesinga, Middel, Post, \& Jochemsen (2008) examined the effect of a multi-week class on spiritual nursing care with undergraduate nursing students' self-perceived competence with providing spiritual nursing care. They were able to show a moderate effect size with the subcategories assessment and implementation of spiritual care, professionalization and improving quality of spiritual care, and personal counselling and support of patients (Van Leeuwen, Tiesinga, Middel, Post, \& Jochemson, 2008).

The questionnaire uses a 29 item Likert scale. It is controversial whether Likert scale data is ordinal or interval level data, but for this study it will be used as interval. Independent $t$ tests were run to compare the means from pre-test scores and post-test scores by domain and by question using PSPP statistical program.

Demographic information collected included race/ethnicity, age, religious affiliation, years of experience, level of education, whether nursing school attended was secular or faith-based, and frequency of providing spiritual care. These data will be analyzed using frequency data and will help describe my subjects. 


\section{Data Collection}

The subjects were given a chance to fill out a survey anonymously via Turning Point survey prior to the intervention. Turning Point is a software program that allows the subject to remotely enter their answer to the survey while in the conference room. The Turning Point expert then ran an answer report that compiled the data from both the pre and post-test. Completed surveys were analyzed using PSPP.

The post tests were done by pen and paper due to time constraints after the presentation and were turned in after the presentation or through interoffice mail by the end of the week. They were not linked to subjects by any identifiable means. These surveys were also analyzed by PSPP.

\section{Ethical Considerations}

The researcher received IRB approval from both Cedarville University and the facility. The participants gave implied consent when filling out the questionnaire as noted in question one. The participants received $1 \mathrm{CE}$ for completion of the education session which was not dependent on them participating in the study. 


\section{Chapter Four}

\section{Results}

\section{Demographic Characteristics}

Demographic characteristics of the participating nurses are presented in Table 3. The sample consisted of 32 pediatric nurses. There were 29 complete pre-tests and 20 complete post-test surveys. The three incomplete pre-tests were discarded from the data set. The majority of the nurses in this study were over 40 years of age (80\%). All of the subjects were female, and the majority of them were Caucasian (97\%). Sixteen of the nurses had Bachelor's Degrees (55.17\%) and six were Master's prepared (20.69\%). Most of the nurses attended secular universities (69\%). This was a very experienced group with many of the nurses having over twenty years nursing experience $(79.6 \%)$. All of the participants identified themselves as Christian (100\%) and all but two identified themselves as active members in a religious group (93\%). The majority of the nurses reported they were providing some amount of spiritual nursing care prior to the education session (89\%). However, only nine stated they provided spiritual nursing care daily $(31.03 \%)$. 
Table 3

Demographic Variables of the Nurses

\begin{tabular}{|c|c|c|}
\hline Variables & $\begin{array}{c}\text { Frequency } \\
(\mathrm{n}=29)\end{array}$ & $\begin{array}{c}\text { Percentage } \\
(100 \%)\end{array}$ \\
\hline \multicolumn{3}{|l|}{ Gender } \\
\hline Female & 29 & $100 \%$ \\
\hline Male & 0 & $0 \%$ \\
\hline \multicolumn{3}{|l|}{ Race } \\
\hline Caucasian & 28 & $97 \%$ \\
\hline Other & 1 & $3 \%$ \\
\hline \multicolumn{3}{|l|}{ Age } \\
\hline $20-30$ & 3 & $9.8 \%$ \\
\hline $30-40$ & 1 & $3.57 \%$ \\
\hline $40-50$ & 9 & $32.14 \%$ \\
\hline $50-60$ & 14 & $50 \%$ \\
\hline+60 & 1 & $3.57 \%$ \\
\hline \multicolumn{3}{|l|}{ Education } \\
\hline Diploma & 3 & $10.3 \%$ \\
\hline $\mathrm{ADN}$ & 5 & $17.2 \%$ \\
\hline $\mathrm{BSN}$ & 16 & $55.17 \%$ \\
\hline Master's & 6 & $20.69 \%$ \\
\hline \multicolumn{3}{|l|}{ University Type } \\
\hline Secular & 20 & $68.96 \%$ \\
\hline Faith Based & 9 & $31.03 \%$ \\
\hline \multicolumn{3}{|l|}{ Religious Affiliation } \\
\hline Christian & 29 & $100 \%$ \\
\hline Other & 0 & $0 \%$ \\
\hline \multicolumn{3}{|c|}{ Practicing Member of Religion } \\
\hline Yes & 27 & $93 \%$ \\
\hline No & 2 & $6.9 \%$ \\
\hline \multicolumn{3}{|l|}{ Years of Experience } \\
\hline $1-5$ & 2 & $6.89 \%$ \\
\hline $6-10$ & 2 & $6.89 \%$ \\
\hline $11-15$ & 1 & $3.45 \%$ \\
\hline $16-20$ & 1 & $3.45 \%$ \\
\hline $20+$ & 23 & $79.3 \%$ \\
\hline \multicolumn{3}{|c|}{ Frequency of Spiritual Care } \\
\hline Not At All & 3 & $10.34 \%$ \\
\hline Daily & 9 & $31.03 \%$ \\
\hline 1-2 X week & 9 & $31.03 \%$ \\
\hline 1-2 X month & 8 & $27.59 \%$ \\
\hline
\end{tabular}




\section{Spiritual Care Competence}

Independent t-tests were used to compare the changes in mean scores from pretest to post-test. The findings are reported in Table 4.1 and Table 4.2. The results of the independent t-tests showed that there was a significant change toward competence from the pre-test scores to the post-test scores in four of the six domains of the SCCS;

Communication, Assessment and Implementation of Spiritual Care, Personal Support and Patient Counseling, and Professionalization and Improving Quality of Spiritual Care. There were no significant changes in the Attitudes Toward Patient's Spirituality or the Referral domains.

The domain of Communication showed a significant change $(t=-2.63, \mathrm{df}=38.43$, $p=0.01, \alpha=0.05)$ between pre-test and post-test scores of competence. Only one of the two questions showed statistically significant differences. However, the other question had a $p$ value of 0.05 .

The domain of Assessment and Implementation of Spiritual Care showed a significant change $(\mathrm{t}=-4.57, \mathrm{df}=47, \mathrm{p}=0.00, \alpha=0.05)$ between pre-test and post-test scores of competence. Five of the six questions in this domain showed a significant change between pre-test and post-test scores of competence. The one question that showed no significant change between pre-test and post-test scores was related to multidisciplinary referral.

The domain of Personal Support and Patient Counseling showed a significant change ( $\mathrm{t}=-4.78, \mathrm{df}=47, \mathrm{p}=0.00, \alpha=0.05)$ between the pre-test and post-test scores of 
competence. All of the individual questions showed significant change between pre-test and post-test scores of competence.

The domain of Professionalization and Improving Quality of Spiritual Care $(\mathrm{t}=$ 3.47, $\mathrm{df}=47, \mathrm{p}=0.00, \alpha=0.05$ ) had a significant change between pre-test and post-test scores of competence. Five of the six questions in this domain showed a significant change in the pre-test and post-test scores of competence. The one question that did not show a significant change was related to feeling confident enough in spiritual care to influence policy development regarding spiritual care.

Table 4.1

Independent t-test by core domains of SCCS

\begin{tabular}{lccccc}
\hline \multicolumn{1}{c}{ Core Domains } & $\begin{array}{c}\text { Pre-test } \\
\mathrm{X} \pm \mathrm{SD}\end{array}$ & $\begin{array}{c}\text { Post-test } \\
\mathrm{X} \pm \mathrm{SD}\end{array}$ & $\mathrm{t}$ & $\mathrm{df}$ & $\mathrm{p}$ value \\
\hline $\begin{array}{l}\text { Attitudes Towards Patient's } \\
\text { Spirituality }\end{array}$ & $4.3 \pm .48$ & $4.44 \pm .35$ & -1.07 & 47 & 0.29 \\
Communication & $3.97 \pm 1.18$ & $4.6 \pm .45$ & -2.63 & 38.43 & 0.01 \\
$\begin{array}{l}\text { Assessment and } \\
\begin{array}{l}\text { Implementation of Spiritual } \\
\text { Care }\end{array}\end{array}$ & $3.53 \pm .56$ & $4.22 \pm .47$ & -4.57 & 47 & .00 \\
$\begin{array}{l}\text { Referral to Professionals } \\
\text { Personal Support and Patient }\end{array}$ & $3.62 \pm .64$ & $4.42 \pm .45$ & -4.78 & 47 & .00 \\
$\begin{array}{l}\text { Counseling } \\
\text { Professionalization and }\end{array}$ & $3.3 \pm .63$ & $3.96 \pm .69$ & -3.47 & 47 & .00 \\
$\begin{array}{l}\text { Improving Quality of Spiritual } \\
\text { Care }\end{array}$ & & & & & \\
\hline
\end{tabular}


Table 4.2

Independent t-test by question

\begin{tabular}{|c|c|c|c|c|c|}
\hline Question & $\begin{array}{l}\text { Pre-test } \\
\mathrm{X} \pm \mathrm{SD}\end{array}$ & $\begin{array}{l}\text { Post-test } \\
\mathrm{X} \pm \mathrm{SD}\end{array}$ & $\mathrm{t}$ & df & $\mathrm{P}$ value \\
\hline $\begin{array}{l}\text { I have sufficient knowledge to } \\
\text { conduct a spiritual assessment. }\end{array}$ & $2.72 \pm 1.13$ & $4.3 \pm .75$ & -6.41 & 43.73 & .00 \\
\hline $\begin{array}{l}\text { I have sufficient knowledge to deliver } \\
\text { spiritual nursing care. }\end{array}$ & $3.34 \pm 1.17$ & $4.30 \pm .57$ & -3.78 & 43.06 & .00 \\
\hline \multicolumn{6}{|l|}{ Attitude Towards Patient Spirituality } \\
\hline $\begin{array}{l}\text { I show unprejudiced respect for a } \\
\text { patient's spiritual/religious beliefs } \\
\text { regardless of his or her } \\
\text { spiritual/religious background. }\end{array}$ & $4.24 \pm .87$ & $4.55 \pm .51$ & -1.42 & 47 & 0.16 \\
\hline $\begin{array}{l}\text { I am open to a patient's } \\
\text { spiritual/religious beliefs, even if } \\
\text { they differ from my own. }\end{array}$ & $4.55 \pm .57$ & $4.5 \pm .51$ & 0.32 & 47 & 0.75 \\
\hline $\begin{array}{l}\text { I do not try to impose my own } \\
\text { spiritual/religious beliefs on a } \\
\text { patient. }\end{array}$ & $4.41 \pm .73$ & $4.45 \pm .6$ & -0.18 & 47 & 0.86 \\
\hline $\begin{array}{l}\text { I am aware of my personal } \\
\text { limitations when dealing with a } \\
\text { patient's spiritual/religious beliefs. }\end{array}$ & $4.0 \pm 1$ & $4.25 \pm .44$ & -1.05 & 47 & 0.3 \\
\hline \multicolumn{6}{|l|}{ Communication } \\
\hline $\begin{array}{l}\text { I can listen actively to a patient's } \\
\text { 'life story' in relation to his or her } \\
\text { illness/handicap. }\end{array}$ & $3.93 \pm 1.28$ & $4.55 \pm .51$ & -2.05 & 47 & 0.05 \\
\hline $\begin{array}{l}\text { I have an accepting attitude in my } \\
\text { dealings with a patient (concerned, } \\
\text { sympathetic, inspiring trust and } \\
\text { confidence, empathetic, genuine, } \\
\text { sensitive, sincere and personal) }\end{array}$ & $4.0 \pm 1.46$ & $4.65 \pm .49$ & -2.22 & 36.4 & 0.03 \\
\hline \multicolumn{6}{|l|}{$\begin{array}{l}\text { Assessment \& Implementation of } \\
\text { Spiritual Care }\end{array}$} \\
\hline $\begin{array}{l}\text { I can report orally and/or in } \\
\text { writing on patient's spiritual } \\
\text { needs. }\end{array}$ & $3.62 \pm 1.08$ & $4.15 \pm .59$ & -2.2 & 44.93 & 0.03 \\
\hline $\begin{array}{l}\text { I can tailor care to a patient's } \\
\text { spiritual needs/problems in } \\
\text { consultation with the patient. }\end{array}$ & $3.31 \pm 1.17$ & $4.15 \pm .59$ & -3.31 & 43.64 & .00 \\
\hline $\begin{array}{l}\text { I can tailor care to a patient's } \\
\text { spiritual needs/problems through } \\
\text { multidisciplinary consultation. }\end{array}$ & $4 \pm .53$ & $4.25 \pm .55$ & -1.59 & 47 & 0.12 \\
\hline
\end{tabular}




\begin{tabular}{|c|c|c|c|c|c|}
\hline Question & $\begin{array}{l}\text { Pre-test } \\
\mathrm{X} \pm \mathrm{SD}\end{array}$ & $\begin{array}{c}\text { Post-test } \\
\mathrm{X} \pm \mathrm{SD}\end{array}$ & $\mathrm{t}$ & $\mathrm{df}$ & $\begin{array}{c}\mathrm{P} \\
\text { value }\end{array}$ \\
\hline $\begin{array}{l}\text { I can record the nursing component } \\
\text { of a patient's spiritual care in the } \\
\text { nursing care plan. }\end{array}$ & $3.28 \pm 1.28$ & $4.15 \pm .59$ & -3.22 & $\begin{array}{l}41 . \\
96\end{array}$ & .00 \\
\hline $\begin{array}{l}\text { I can report in writing on a patient's } \\
\text { spiritual functioning. }\end{array}$ & $3.28 \pm .88$ & $4.25 \pm .64$ & -4.23 & 47 & .00 \\
\hline $\begin{array}{l}\text { I can report orally on a patient's } \\
\text { spiritual functioning. }\end{array}$ & $3.69 \pm 0.6$ & $4.4 \pm 0.6$ & -4.06 & 47 & .00 \\
\hline \multicolumn{6}{|l|}{ Referral } \\
\hline $\begin{array}{l}\text { I can effectively assign care for a } \\
\text { patient's spiritual needs to another } \\
\text { care provider/care worker/care } \\
\text { discipline. }\end{array}$ & $3.76 \pm .74$ & $4.15 \pm .75$ & -1.82 & 47 & 0.08 \\
\hline $\begin{array}{l}\text { At the request of a patient with } \\
\text { spiritual needs, I can, in a timely and } \\
\text { effective manner, refer him or her to } \\
\text { another care worker. }\end{array}$ & $4.38 \pm .86$ & $4.55 \pm .51$ & -0.79 & 47 & 0.43 \\
\hline $\begin{array}{l}\text { I know when I should consult a } \\
\text { spiritual advisor concerning a } \\
\text { patient's spiritual care. }\end{array}$ & $3.86 \pm .99$ & $4.2 \pm .52$ & -1.39 & 47 & 0.17 \\
\hline \multicolumn{6}{|l|}{ Personal Support and Patient Counseling } \\
\hline $\begin{array}{l}\text { I can provide a patient with spiritual } \\
\text { care. }\end{array}$ & $3.52 \pm .95$ & $4.4 \pm .5$ & -3.8 & 47 & .00 \\
\hline $\begin{array}{l}\text { I can evaluate the spiritual care that I } \\
\text { have provided in consultation with } \\
\text { the patient and in the } \\
\text { disciplinary/multi-disciplinary team. }\end{array}$ & $3.34 \pm .94$ & $4.1 \pm .64$ & -3.13 & 47 & .00 \\
\hline $\begin{array}{l}\text { I can give a patient information } \\
\text { about spiritual facilities within the } \\
\text { care institution. }\end{array}$ & $3.83 \pm 1.07$ & $4.3 \pm .8$ & -1.67 & 47 & 0.1 \\
\hline $\begin{array}{l}\text { I can help a patient continue his or } \\
\text { her daily spiritual practices. }\end{array}$ & $3.69 \pm 1.31$ & $4.55 \pm .51$ & -2.78 & 47 & 0.01 \\
\hline $\begin{array}{l}\text { I can attend to a patient's spirituality } \\
\text { during the daily care. }\end{array}$ & $3.52 \pm 1.02$ & $4.55 \pm .51$ & -4.17 & 47 & .00 \\
\hline $\begin{array}{l}\text { I can refer members of a patient's } \\
\text { family to a spiritual } \\
\text { advisor/pastor,etc if they ask me and } \\
\text { or if they express spiritual needs. }\end{array}$ & $3.83 \pm 1.39$ & $4.6 \pm .5$ & -2.74 & $\begin{array}{l}37 . \\
62\end{array}$ & 0.01 \\
\hline \multicolumn{6}{|l|}{$\begin{array}{l}\text { Professionalization \& Improving the } \\
\text { Quality of Spiritual Care }\end{array}$} \\
\hline $\begin{array}{l}\text { Within the department, I can } \\
\text { contribute to quality assurance in the } \\
\text { area of spiritual care. }\end{array}$ & $3.48 \pm .87$ & $4 . \pm .73$ & -2.18 & 47 & 0.03 \\
\hline
\end{tabular}




\begin{tabular}{lccccc}
\hline \multicolumn{1}{c}{ Question } & $\begin{array}{c}\text { Pre-test } \\
\text { X } \pm \text { SD }\end{array}$ & $\begin{array}{c}\text { Post-test } \\
\text { X } \pm \text { SD }\end{array}$ & t & df & $\begin{array}{c}\text { P } \\
\text { value }\end{array}$ \\
\hline $\begin{array}{l}\text { Within the department, I can } \\
\text { contribute to professional } \\
\text { development in the area of spiritual } \\
\text { care. }\end{array}$ & $3.41 \pm .68$ & $3.95 \pm .69$ & -2.7 & 47 & 0.01 \\
$\begin{array}{l}\text { Within the department, I can identify } \\
\text { problems relating to spiritual care in }\end{array}$ & $3.45 \pm .87$ & $4.1 \pm .79$ & -2.68 & 47 & 0.01 \\
$\begin{array}{l}\text { peer discussions session. } \\
\text { I can coach other care workers in the } \\
\text { area of spiritual care delivery to }\end{array}$ & $3.07 \pm 1.07$ & $4.05 \pm .76$ & -3.54 & 47 & .00 \\
$\begin{array}{l}\text { patients. } \\
\text { I can make policy recommendations } \\
\text { on aspects of spiritual care to the } \\
\text { management of the nursing ward. }\end{array}$ & $3.41 \pm .91$ & $3.75 \pm .85$ & -1.31 & 47 & 0.2 \\
$\begin{array}{l}\text { I can implement a spiritual care } \\
\text { improvement project in the nursing } \\
\text { ward. }\end{array}$ & $2.97 \pm 1.02$ & $3.9 \pm .85$ & -3.37 & 47 & .00 \\
\hline
\end{tabular}




\section{Chapter 5}

\section{Discussion}

This pilot study supports the original hypothesis that there will be a change in pediatric nurse's competence following the in service on the Faith-Hope-Love Model of Spiritual Care for Nurses. The study showed significant changes in four of the six domains of the SCCS: Communication $(\mathrm{t}=-2.63, \mathrm{df}=38.43, \mathrm{p}=0.01, \alpha=0.05)$, Assessment and Implementation of Spiritual Care $(\mathrm{t}=-4.57, \mathrm{df}=47, \mathrm{p}=0.00, \alpha=0.05)$, Personal Support and Patient Counseling $(\mathrm{t}=-4.78, \mathrm{df}=47, \mathrm{p}=0.00, \alpha=0.05)$, and Professionalization and Improving Quality $(\mathrm{t}=-3.47$, df $47, \mathrm{p}=0.00, \alpha=0.05)$. There were statistically significant changes in the scores on 18 of the 29 survey items.

The first two questions on the survey pertained to increased knowledge. I wanted to see if the nurses felt like they gained knowledge on how to provide spiritual nursing care. There was, however, no validated survey tool that focused on knowledge of spiritual care and therefore these results are interesting, but not a part of proving the hypothesis.

The domain of Attitudes toward Patients Spirituality had high pre-test scores and therefore it is not surprising that the means of the post-test scores were not significantly increased. This group of nurses already had a high respect for the spirituality of their patients before the education session. This supports the literature that stated nurses respect spirituality but are unsure of how to provide spiritual nursing care (Ross, 2006, McEwen, 2004, Carr, 2010). 
The domain of Referral also did not show a significant change. The education session was not focused on how to refer a patient for spiritual care. The focus was on how a nurse can care for a person's spirit during daily interactions with their patients and others. Therefore, I was not expecting to see statistically significant results in this category.

There were six questions that had significant results that best describe the change in nurses' competence as the answers changed from neither agree or disagree to between agree and strongly agree. They also best fit the objectives of the education session, which are as follows: I have an accepting attitude in my dealings with a patient (concerned, sympathetic, inspiring trust and confidence, empathetic, genuine, sensitive, sincere, and personal), I can tailor care to a patient's spiritual needs/problems in consultation with the patient, I can report orally on a patient's spiritual functioning, I can provide a patient with spiritual care, I can help a patient continue his or her daily spiritual practices, and I can attend to a patient's spirituality during the daily care.

After extensive research on spiritual nursing care, it became apparent to me that much of the spiritual nursing research is 1) qualitative, 2) use nursing students as subjects, and 3) don't address spiritual nursing care from a Biblical perspective. Spiritual nursing care is a well-discussed topic, and the Joint Commission and American Nurses Association state that it is a necessary part of patient care (American Nurses Association, 2010, \& The Joint Commission, 2001). Yet nurses are still not consistently providing spiritual nursing care (Balboni, et al., 2007). Only $31 \%$ of the nurses surveyed in this study were performing spiritual nursing care on a daily basis. 
The results of this study support what similar studies have found with nursing students. Meyer (2003) determined that students with education on spiritual care are more likely to describe increased awareness of spirituality in their nursing practice. Burkhart \& Schmidt (2012) showed a significant increase in students' perceived ability to assess patient's spiritual needs and promote spiritual connections with patients after receiving training in spiritual care.

\section{Links to Model}

The Faith-Hope-Love Model of Spiritual Care for Nurses is based on the idea that it is necessary to understand the spirit from a Biblical Perspective in order to have competence in providing spiritual nursing care to patients. The education session focused on how to define the spirit using Biblical understanding of the spirit. The presenter explained how the spirit can be broken and healed, and how nurses have spiritual interactions with their patients and other staff in their every interaction. The presenter then educated the nurses on interventions for the spirit. Although this was a pilot study, and the sample size and power was very small, the significant results in the four domains addressed by the education session suggest that education on spiritual nursing care using this model has the potential to increase spiritual care competence in the nursing staff.

\section{Limitations and Strengths}

This study is a pilot study and, therefore, lends itself to some limitations. The sample was a convenience sample at a pediatric hospital in the Midwest, and it was a small sample of just 29 nurses. This is a very small percentage of the nursing body at the facility. It is an ongoing problem in hospital education to find a time that accommodates 
the schedules of the nurses in many different departments working varying shifts. Because of the small sample size the power of the study is very low and, therefore, increases the chance of a type II error in the study.

The second limitation of this study is that independent $\mathrm{t}$ - tests had to be run instead of paired t-tests even though the pre-test group and the post-test group were the same subjects. This limits my ability to tell whether individual subjects mean scores increased in the six domains of the SCCS. The original study design was for the pre-test and post-test to both be completed by Turning Point prior to and directly following the education session. During the first session, it took longer than anticipated to complete the pre-test via Turning Point, and the education session began to run over the allotted time. The subjects were starting to leave the auditorium, so it became necessary for me to give them the post-test on paper to return to me at a later date. There was no way to link the paper copy to the individual's Turning Point Data.

Lastly, the subjects all identified themselves as Christian, and the majority were practicing members of their faith. I believe this is due to the way the class was required to be advertised by the institution. There were some concerns about the use of Biblical education and Christian themes in a secular institution. Therefore, it was required that the advertisement was very specific about this class being taught from a Biblical perspective. This makes it very unlikely that people who practice other religions would attend the presentation. This limits external validity because the results of the study are not generalizable to other populations. However, my intention was to reach Christian 
nurses who believe the teachings of the Bible and help them understand the spirit and how to provide spiritual care.

The strengths of this study are also valuable to consider. This pilot study is the first to study the effect of a one hour education session on competence of experienced nurses. It is also the first study to use the Faith-Hope-Love Model of Spiritual Care for Nurses developed by Dr. Sharon Christman. This study used a validated survey tool (SCCS) that could be used in further research on the model. Lastly, the in service was well received by the facility. The evaluations that were required for the $\mathrm{CE}$ were positive, and the nurses mentioned that they learned that love is the most important need of the spirit. Many of the nurses mentioned that their take home message from the session was to remember that every interaction with another human being is a spiritual interaction, and that love is the most important spiritual need. This study planted a seed at the facility, and the hope is that the patients and families will benefit from the competence the nurses gained during their participation in this study.

\section{Implications for Practice}

Spiritual nursing care is a much discussed topic in nursing literature, but there have been no quantitative studies on models for teaching nurses spiritual care. This small pilot study has started the research on the Faith-Hope-Love Model, and has suggested that this model made an impact on the nurses at the facility. It was apparent in the in service sessions that Christian nurses are still looking for ways to understand spiritual care and make it a part of their practice. They understand that health care includes 
spiritual care. This model could be used in both university and hospital educational programs to better educate nurses to provide spiritual care.

As Advanced Practice Nurses we need to be assessing where the deficits in patient care are in our departments. Prior to beginning this research, nurses had approached me about their uncertainty in providing spiritual care. This in service provided needed knowledge that increased a few nurse's feelings of competence in providing spiritual care. Patient care would benefit from everyone approaching their patients with love, providing them hope, and finding ways to support their faith not only in God, but in you and other medical staff.

\section{Recommendations for Future Research}

As stated before, this is the first research study that has used Dr. Christman's model. Future research on this model and the increased nursing competence should be done on a larger scale to determine the effectiveness of this method of teaching. It would be interesting to study both practicing nurses and nursing students who have completed education based on this model. These studies should be completed in both secular and faith based hospitals and nursing schools.

It was the initial intention of this study to look at competence of nurses over an extended time, but time constraints did not allow that to happen. Longitudinal studies should be done using the SCCS to determine if the education would change actual nursing behavior in their daily practice. This would be useful in letting researchers know whether the education increased the nurse's feelings of competence long term. One 
would like to see that the long term effects of such education transfer to better care for patients.

Further research on the effects of spiritual nursing care provided using the model on patient's feelings of loneliness, fear, and hopelessness should be the next step. Teaching spiritual nursing care is useless unless it is being used to benefit the patients. Therefore further research should focus closely on the patient experience and whether their spiritual needs of faith, hope, and love are being met more consistently by nursing staff who have received this education.

\section{Summary}

The lack of spiritual nursing care in hospitals continues to be a problem in the United States. Research has shown that spiritual health is a very important part of healing and health status. The purpose of this pilot study was to determine if spiritual nursing care education based on Biblical truth influences the competence levels of spiritual caregiving in Pediatric nurses. The Bible very clearly tells us that the spiritual needs are faith, hope, and most of all love. Loving people is sometimes a difficult thing to do in nursing with tight time schedules, staffing shortages, and difficult situations with our patients. The nurses that participated in this study have gained insight into how to make every interaction with their patient a chance to care for their spirit. It is my hope that this improves the level of patient care at the facility. The results of this pilot study are significant even though the sample size is small, and should encourage further research in this area. 
The strength of this study design is a pilot study will provide information to help guide further research on spiritual nursing care education. The weakness is these studies have minimal external validity due to extremely small sample size. There was also a possibility of interference of maturation and history due to the time between pre-test and post-test. However, the time between the tests in this study was relatively short which helps increase validity. 


\section{References}

American Nurses Association . (2010). Code of Ethics. Retrieved from http://www.nursingworld.org/MainMenuCategories/EthicsStandards/CodeofEthic sforNurses/Code-of-Ethics.pdf

Astrow, A. B., Wexler, A., Texeira, K., He, M. K., \& Sulmasy, D. P. (2007). Is failure to meet spiritual needs associated with cancer patients perceptions of quality of care and their satisfaction with care. Journal of Clinical Oncology, 25, 5753-5757.

Balboni, T. A., Vanderwerker, L. C., Block, S. D., Paulk, M. E., Christopher, S., Peteet, J. R., \& Prigerson, H. G. (2007). Religiousness and spiritual support among advanced cancer patients and associations with end of life treatment preferences and quality of life. Journal of Clinical Oncology, 25(5), 555-560.

Bria, I. (1992). A fresh breath of spirituality. Ecumenical Review, 44(4), 429-432.

Burkhart, L., \& Hogan, N. (2008). An experiential theory of spiritual nursing practice. Qualitative Health Research, 18, 928-938.

Burkhart, L., \& Schmidt, W. (2012). Measuring effectiveness of a spiritual care pedagogy in nursing education. Journal of Professional Nursing, 28(5), 315-21. http://dx.doi.org/10.1016/j.profnurs.2012.03.003

Carr, T. (2010). Facing existential realities: Exploring barriers and challenges in spiritual nursing care. Qualitative Health Research, 20(10), 1379-1392. http://dx.doi.org/10.1177/1049732310372377

Christman, S. (2013, April). Spirit: A biblical study. In , Spirit: A biblical study. Symposium conducted at the Cedarville University, Cedarville, Oh. 
Delaney, C. (2005). The spirituality scale: Development and psychometric testing of a holistic instrument to assess the human spiritual dimension. Journal of Holistic Nursing, 23(2), 145-167.

Grove, S. K. (2007). Statistics for health care research: A practical workbook. St. Louis, MO: Saunders Elsevier.

Highfield, M. E., Taylor, E. J., \& Amenta, M. G. (200). Preparation to care: The spiritual care education of oncology and hospice nurses. Journal of Hospice and Palliative Nursing, 2(2), 53-63.

Hodge, D. R., \& Horvath, V. E. (2011). Spiritual needs in health care settings: A qualitative meta-synthesis of clients' perspectives of 11 studies. Social Work, 56(4), 306-16.

Hummel, L., Galek, K., Murphy, K. M., Tannenbaum, H. P., \& Flannelly, L. T. (2008). Defining spiritual care: An exploratory study. Journal of Health Care Chaplaincy, $15,40-51$.

Keefe, S. (2005). Infusing spirituality in nursing: A literature review. Nursing Education Today, 41-42.

Kenny, G., \& Ashley, M. (2005). Children's student nurses knowledge of spirituality and its implications for educational practice. Journal of Children's Healthcare, 9(3), 174-85. http://dx.doi.org/Retrieved from

Koenig, H. G. (2008). Medicine, religion, health: Where science and spirituality meet. West Conshohocken, PA: Templeton Foundation Press. 
Kolander, C. (2002). Spiritual and personal wellness: Advice to caregivers on living life more full. Church \& Society, 92(4), 35-39.

Lemmer, C. (2002). Teaching the spiritual dimension of nursing care: A survey of US baccalaureate nursing programs. The Journal of Nursing Education, 41(11), 482490.

Macrae, J. (1995). Nightingale's spiritual philosophy and its significance for modern nursing. Journal of Nursing Scholarship, 27(1), 8-10.

McEwen, M. (2004). Analysis of spirituality content in nursing textbooks. Journal of Nursing Education, 43(1), 20-30.

Meyer, C. L. (2003). How effectively are nurse educators preparing students to provide spiritual care? Nurse Educator, 28(4), 185-90.

Monroe, P. G., \& Schwab, G. M. (2009). God as healer: A closer look at Biblical images of inner healing with guiding questions for counselors. Journal of Psychology and Christianity, 28(1), 121-129.

National Council for State Boards of Nursing. (2005). Business book: NCSBN 2005 annual meeting. Chicago, IL: Author.

Pesut, B. (2008). Spirituality and spiritual nursing care in nursing fundamentals textbooks. Journal of Nursing Education, 47(4), 167-173.

Ross, L. (2006). Spiritual care in nursing. Journal of Advanced Nursing, 15(7), 852-862.

Shelly, J. A., \& Miller, A. B. (1999). Called to care: A Christian theology of nursing. Downers Grove, IL: InterVarsity Press. 
The Joint Commission. (2001). Joint Commission Requirements. Retrieved from Www.jointcommission.org

Van Dover, L., \& Pfeiffer, J. B. (2001). Spiritual care in nursing practice: A close up view. Nursing Forum, 36(3), 18-30.

Van Leeuwan, R., \& Cusveller, B. (2004). Nursing competencies for spiritual care. Journal of Advanced Nursing, 48(3), 234-46.

Van Leeuwen, R., Tiesinga, L. J., Middel, B., Post, D., \& Jochemson, H. (2008). The effectiveness of an educational programme for nursing students on developing competence in the provision of spiritual care. Journal of Clinical Nursing, 17, 2768-2781.

Van Leeuwen, R., Tieslinga, L., Middel, B., Post, D., \& Jochemsen, H. (2009). The validity and reliability of an instrument to asses nursing competencies in spiritual care. Journal of Clinical Nursing, 18(20), 2857-2869. http://dx.doi.org/doi:10.1111/j.1365-2702.2008.02594.x

Wallace, M., Campbell, S., Grossman, S., Shea, J., Lange, G., \& Quell, T. (2008). Integrating spirituality into nursing. Journal of Nursing Education Scholarship, $5(1), 1-6$.

Weidner, N. J., Cameron, M., Lee, R. C., McBride, J., \& Mathias, E. J. (2011). End of life care for the dying child: What matters most to parents. Journal of Palliative Care, 27, 279-86. http://dx.doi.org/Retrieved from 
Yardley, S. J., Walshe, C. E., \& Parr, A. (2009). Improving training in spiritual care: A qualitative study exploring patient perceptions of professional education requirements. Palliative Medicine, 23(7), 601-607. 


\section{Appendix A}

\section{Spiritual Care Competence Survey}

\section{Default Question Block}

You are invited to participate in a research study to examine whether spiritual nursing care education provided to
practicing pediatric nurses improves your feelings of competence in providing spiritual nursing care to your patients.

If you agree to participate in this research study you will be asked to complete a brief questionnaire today via Turning Point, again immediately after the spiritual care seminar and again two weeks after the spiritual care seminar-all via Turning Point. This survey contains 9 demographic questions (age, gender and so forth) and 29 spiritual care competence questions (for example: I have the competence to conduct a spiritual care assessment).

By completing this survey you are giving consent for the researchers to use this information in their research study.

\section{The Benefit for Nurses in general:}

The Joint Commission and the Ohio Board of Nursing Code of Ethics state that caring for a patient's spirit is an essential part of nursing care. However, researchers have shown that patient's do not feel as if they are receiving sufficient spiritual care. Other studies have also shown that nurses feel incompetent in providing adequate spiritual nursing care. The results of this study will help me know whether a one-time spiritual care seminar is helpful in increasing nurses' competence in providing spiritual care.

\section{The Benefit for You:}

There is no specific benefit for you in participating in this research study. You are invited to participate in the onehour spiritual care seminar and will receive one hour of continuing education credit for the seminar whether you complete this survey or not.

If you change your mind about participating. you can withdraw at any time during the study by sending written notice to the study investigator at LinegangB Bchildrensdayton.org. Your participation is completely voluntary. Your decision about whether or not to participate or to stop participating will not jeopardize your future relations with Dayton Children's.

There is no risk to you by participating in this study and the information about you collected for this research will be protected by removing any participant identifiers. All study information will be stored in secured research files and will not be identifiable to the researcher. Dayton Children's Institutional Review Board (IRB) and/or the Office of Human Research may inspect study records so that the research can be properly monitored. If results of this study are reported in journals, at scientific meetings, or used for educational purposes, the people who participated in this study will not be identified.

If you have questions about this study, please contact the study investigator at (937) 360-3971.

What is your Gender?
Male
Female 
What is your race/ethnicity
Caucaslan
African American
Astan
Hispanic
other

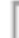

Please select your age?
20-30
$30-40$
40-50
$50-60$
$+60$

What is your level of education?
Assoclate's Degree
Bachelor's Degree
Diploma
Master's

Was your university a secular or faith-based institution?

Secular

Falth-based

Are you a practicing member of a religious faith?

Yes

No

If Yes, what is your religious affiliation? 

Christlan
Jewish
Mus llm
Buddhlst
other

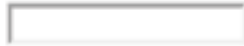

How many Years of Nursing Experience do you have?
(1-5
6-10
11-15
(16-20
over 20

How often do you think you provide spiritual care each week?
Not at all
Dally
1-2 $x$ weekly
1-2 $x$ a month

I have sufficient knowledge to conduct a spiritual assessment.

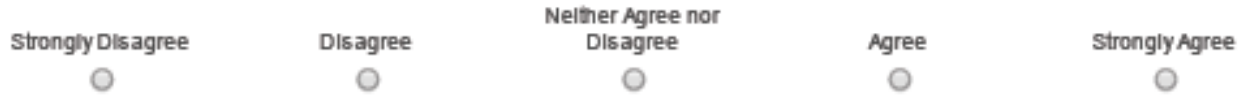

I have sufficient knowledge to deliver spiritual nursing care.

\begin{tabular}{|c|c|c|}
\hline Strongly Disagree & Disagree & $\begin{array}{c}\text { Nelther Agree nor } \\
\text { Dlsagree }\end{array}$ \\
\hline 0 & 0 & 0 \\
\hline
\end{tabular}

Agree

Strongly Agree

O

O

I show unprejudiced respect for a patient's spiritual/religious beliefs regardless of his or her spiritual/religious background 
I am open to a patient's spiritual/religious beliefs, even if they differ from my own

Strongly Dis agree

O

Disagree

○
Nelther Agree nor

Disagree

$\mathrm{O}$

I am aware of my personal limitations when dealing with a patient's spirituaV/religious beliefs

\begin{tabular}{|c|c|c|c|c|}
\hline \multicolumn{5}{|c|}{ Nelther Agree nor } \\
\hline Strongly Dis agree & Disagree & Disagree & Agree & Strongly Agree \\
\hline 0 & 0 & 0 & 0 & 0 \\
\hline
\end{tabular}

I can listen actively to a patient's 'iffe story' in relation to his or her illness/handicap

Strongly Dis agree

$\mathrm{O}$
Disagree

O
Nelther Agree nor Disagree

$\mathrm{O}$
Agree

$\mathrm{O}$
Strongly Agree

O

I have an accepting attitude in my dealings with a patient (concerned, sympathetic, inspiring trust and confidence, empathetic, genuine, sensitive, sincere and personal)

Strongly Disagree

O
Disagree

O

Nelther Agree nor

Disagree

$\mathrm{O}$

Agree

O

Strongly Agree

O

I can report orally and/or in writing on a patient's spiritual needs

Strongly Disagree

0
Disagree

O

\section{Nelther Agree nor \\ Disagree}

$\mathrm{O}$
Agree

O
Strongly Agree

O 
I can tailor care to a patient's spiritual needs/problems in consultation with the patient

\begin{tabular}{|c|c|c|c|c|}
\hline \multicolumn{5}{|c|}{ elther Agree nor } \\
\hline Strongly Disagree & Disagree & Disagree & Agree & Strongly Agree \\
\hline 0 & 0 & 0 & 0 & 0 \\
\hline
\end{tabular}

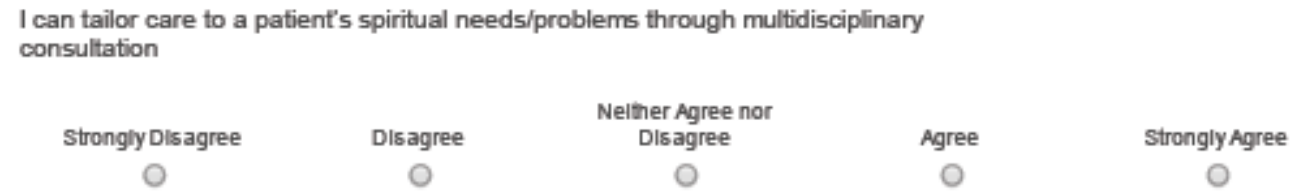

I can record the nursing component of a patient's spiritual care in the nursing plan

Nelther Agree nor

O

Disagree

Disagree

Agree

Strongly Agree

$\mathrm{O}$

$\mathrm{O}$

$\mathrm{O}$

I can report in writing on a patient's spiritual functioning

\begin{tabular}{|c|c|c|c|c|}
\hline \multicolumn{5}{|c|}{ elther Agree nor } \\
\hline Strongly Disagree & Disagree & Disagree & Agree & Strongly Agree \\
\hline 0 & 0 & $\mathrm{O}$ & $\mathrm{O}$ & 0 \\
\hline
\end{tabular}

I can report orally on a patient's spiritual functioning

Strongly Disagree

O
Disagree

O
Nelther Agree nor

Disagree

O
Agree

O

Agree

Disagree

$\mathrm{O}$

Strongly Agree

O

I can effectively assign care for a patient's spiritual needs to another care provider/care worker/care discipline

Strongly Disagree

O
Disagree

$\sqrt{2}$

$\bigcirc$
Strongly Agree

O

At the request of a patient with spiritual needs, I can in a timely and effective manner refer him or her to another care worker (e.g. a chaplain/the patient's own priest/imam) 


$\begin{array}{cccc}\text { Strongly Disagree } & \text { Disagree } & \text { Nelther Agree nor } & \text { Agree } \\ 0 & 0 & \text { Disagree } & \text { Strongly Agree }\end{array}$

I know when I should consult a spiritual advisor concerning a patient's spiritual care

Strongly Disagree

O

Disagree

$\mathrm{O}$

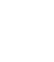
Nelther Agree nor
Disagree

O
Agree

O

Strongly Agree

O

I can provide a patient with spiritual care

Strongly Disagree

O
Disagree
Nelther Agree nor

Disagree

○
Agree

O
Strongly Agree

O

I can evaluate the spiritual care that I have provided in consultation with the patient and in the disciplinary/multi-disciplinary team

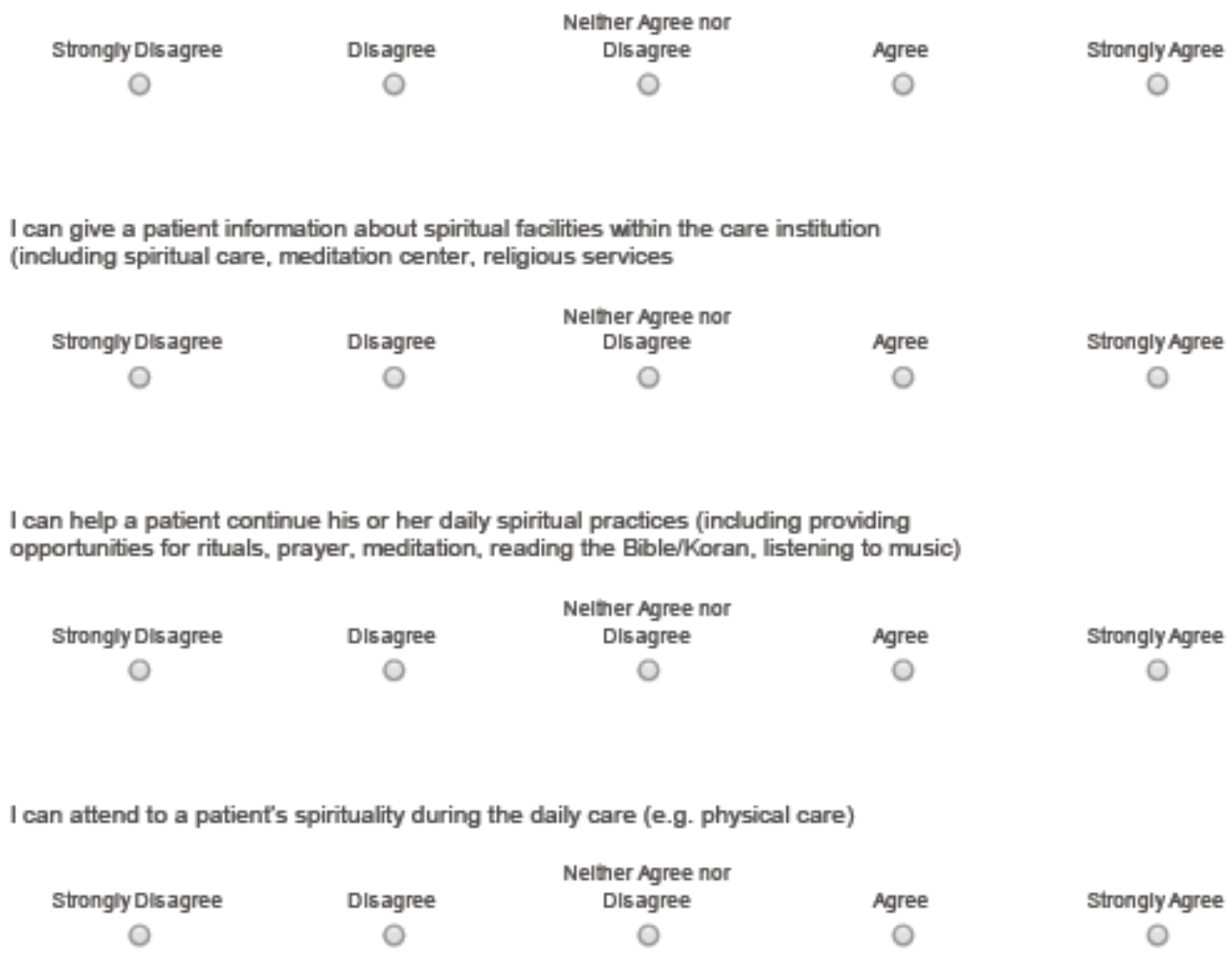


I can refer members of a patient's family to a spiritual advisor/pastor, etc. if they ask me and/or if they express spiritual needs

\begin{tabular}{|c|c|c|c|c|}
\hline \multicolumn{5}{|c|}{ elther Agree nor } \\
\hline sto & Disagree & Dlsagree & Agree & Strongly Agree \\
\hline 0 & 0 & 0 & 0 & 0 \\
\hline
\end{tabular}

Within the department, I can contribute to quality assurance in the area of spiritual care

\begin{tabular}{|c|c|c|c|c|}
\hline strongly Disagree & Dlsagree & $\begin{array}{l}\text { Nelther Agree nor } \\
\text { Dlsagree }\end{array}$ & Agree & Strongly Agree \\
\hline 0 & 0 & 0 & 0 & 0 \\
\hline
\end{tabular}

Within the department, I can contribute to professional development in the area of spiritual care

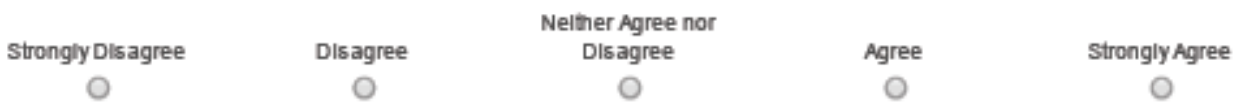

Within the department, I can identify problems relating to spiritual care in peer discussions session

Strongly Disagree

○
Disagree

○
Nelther Agree nor
Disagree

O
Agree

O
Strongly Agree

O

I can coach other care workers in the area of spiritual care delivery to patients

Strongly Dis agree

O
Disagree

○
Nelther Agree nor

Disagree

O
Agree

O
Strongly Agree

0

I can make policy recommendations on aspects of spiritual care to the management of the nursing ward

$\begin{array}{ccc}\text { Strongly Disagree } & \text { Disagree } & \text { Nelther Agree nor } \\ 0 & 0 & \text { Disagree }\end{array}$

Agree

$\mathrm{O}$

Strongly Agree

O

I can implement a spiritual-care improvement project in the nursing ward

Strongly Disagree

0
Disagree

O

\section{Nelther Agree nor}

Disagree

O
Agree

0
Strongly Agree

$O$ 
